\title{
RANCANGAN SISTEM PALANG PINTU OTOMATIS PADA JALUR BUS RAPID TRANSIT (BRT) BERBASIS ARDUINO
}

\author{
Akhmad Fauzi ${ }^{1}$, Mushlihudin ${ }^{2}$ \\ ${ }^{1}$ Program Studi Teknik Elektro, Fakultas Teknologi Industri, Universitas Ahmad Dahlan \\ 2Program Studi Teknik Informatika, Fakultas Teknologi Industri, Universitas Ahmad Dahlan \\ Kampus III, Jln. Prof. Dr. Soepomo,S.H. Umbulharjo, Yogyakarta 55161 \\ e-mail: akhmadfauzi052@gmail.com¹, mushlihudin@tif.uad.ac.id²
}

\begin{abstract}
Transjakarta bus was officially operated in 2004 and until now there are thirteen corridors that operate. The purpose of this bus operation is to solve the congestion problem in DKI Jakarta. Its separate lanes with the public lanes makes Transjakarta buses run normally even though the public lane next to it is jammed. As time passes, new problems arise in this system, such as burned buses to other vehicles which go on the bus lane illegally paths. Due to many illegal passersby from the society, there are also many accidents in the lane. This study aims to design an automatic doorstop system on Transjakarta bus lanes, so that the illegal passersby can be minimized in order to eliminated the accident figure. This system is a miniature with a scale of 1:25 and is positioned on the Transjakarta bus lanes that intersect with other vehicles turning Uturn lane. The miniature is using Arduino Leonardo as a microprocessor and a servo motor as a crossing barrier that moves 90 degrees. Reed switch sensors are used as the bus detectors that are placed in the beginning and end of the path of the system. Based on the research that has been done, we obtained a result that the system is running well and that the reed switch sensors can be applied as a bus detector. The important elements in this system are, when the bus passes through the sensor, its speed has to be adjusted so that the sensor can detect the bus when the bus passes it.
\end{abstract}

Keywords: transjakarta bus; arduino leonardo; servo motor; reed switch sensor.

\section{Abstrak}

Bus Transjakarta resmi beroperasi Pada tahun 2004 dan hingga saat ini jumlah koridor yang beroperasi berjumlah 13 buah. Tujuan dioperasikannya bus ini adalah untuk memecah masalah kemacetan yang ada di DKI Jakarta. Jalur bus yang terpisah dengan jalur umum membuat bus Transjakarta dapat berjalan normal meski jalur umum di sebelahnya terjadi kemacetan. Seiring berjalannya waktu, muncul masalah-masalah baru pada sistem ini, seperti bus yang terbakar hingga penerobosan jalur secara ilegal oleh kendaraan lain. Akibat banyak penerobosan jalur yang dilakukan oleh masyarakat, mengakibatkan banyak terjadi kecelakaan di jalur tersebut. Penelitian ini bertujuan untuk merancang sistem palang pintu otomatis pada jalur Bus Transjakarta, sehingga penerobosan jalur dapat diminimalisir sehingga diharapkan angka kecelakan dapat dihilangkan. Sistem ini berupa miniatur dengan skala 1:25 dan diposisikan pada jalur bus Transjakarta yang bersinggungan dengan jalur putar balik kendaraan lain. Menggunakan Arduino Leonardo sebagai mikroprosesor dan motor servo sebagai penggerak palang pintu yang bergerak 90 derajat. Sensor reed switch digunakan sebagai pendeteksi bus yang diletakkan diawal dan diakhir jalur dari sistem ini. Berdasarkan penelitian yang sudah dilakukan, didapatkan hasil bahwa sistem ini berjalan dengan baik dan sensor reed switch dapat diaplikasikan sebagai pendeteksi bus. Unsur-unsur penting dalam sistem ini adalah saat bus melewati sensor, kecepatan bus harus disesuaikan sehingga sensor dapat mendeteksi bus, saat bus melintasinya.

Kata kunci: bus transjakarta; arduino leonardo; motor servo; sensor reed switch. 


\section{Pendahuluan}

Pertumbuhan penduduk Provinsi DKI Jakarta berdasarkan data Badan Pusat Statistik (BPS) pada tahun 2015 mencapai 10.177,9 ribu jiwa [1], dengan luas wilayah $661,5 \mathrm{~km}^{2}$ membuat Jakarta menjadi Provinsi tepadat dan salah satu masalah yang dihadapi hingga saat ini adalah kemacetan. Berdasarkan data yang dikeluarkan oleh Direktorat Lalu Lintas Polda Metro Jaya pada tahun 2014, jumlah kendaraan bermotor di Jakarta dan sekitarnya bertambah sebanyak 5.500 hingga 6.000 unit kendaraan per hari. Jumlah tersebut didominasi oleh pertambahan sepeda motor yang mencapai 4.000 hingga 4.500 per hari, Sedangkan kendaraan roda empat mengalami pertumbuhan sebanyak 1.600 unit per hari [2].

Salah satu tujuan dibangunnya bus Transjakarta adalah untuk mengatasi persoalan sosial dan teknis dalam bertransportasi di kota Jakarta [3]. Bus Transjakarta yang diproyeksikan sebagai transportasi masal yang diharapkan dapat terhindar dari macet dijalanan di Jakarta. Jalur bus yang terpisah dengan jalur umum membuat bus Transjakarta dapat berjalan normal meski jalur umum di sebelahnya terjadi kemacetan. Di beberapa lokasi jalur bus Transjakarta yang terpisah dengan jalur kendaraan pribadi, dimanfaatkan oleh beberapa masyarakat dengan sengaja memasuki jalur bus Transjakarta guna menghindari kemacetan yang ada di jalur umum.

Jalur bus Transjakarta tidak luput dari kecelakaan. Kecelakaan itu sendiri terjadi karena penerobosan jalur bus oleh masyarakat. Bahkan pelanggaran ini sering kali berakibat pada kecelakaan yang cukup fatal. Tercatat pada tahun 2010 data dari Kepolisian Daerah Metro Jakarta mencatat jumlah kecelakaan yang terjadi di jalur Transjakarta mencapai 430 kasus. Dari data tersebut, sebanyak 14 orang meninggal dunia, 18 orang mengalami luka berat, dan 99 orang menderita luka ringan [2]. pihak pengelola sudah melakukan beberapa cara untuk sterilisasi jalur seperti bekerja sama dengan kepolisian untuk memberi sanksi berupa tilang bagi pengendara yang menerobos jalur Transjakarta dan juga telah memasang portal penutup yang dioperasikan secara manual dengan tenaga manusia. Walaupun palang pintu sudah dijaga oleh petugas, nyatanya penerobosan masih sering terjadi terutama di jam-jam sibuk lalu lintas. Para penerobos biasanya memasuki jalur Transjakarta pada bagian jalur yang tidak ditutupi oleh separator.

\section{Metode Penelitian}

\subsection{Perancangan Sistem}

Perancangan sistem dilakukan dalam dua tahap yaitu perancangan perangkat keras ( hardware) dan perangkat lunak (software). Untuk mempermudah dalam perancangan perangkat keras maka harus mengacu pada data sheet yang ada dari setiap perangkat yang digunakan, seperti datasheet pada Arduino Leonardo dan datasheet reed switch sensor.

\subsubsection{Perancangan Perangkat Keras}

Perancangan terdiri dari perancangan berbasis elektronik dan tidak elektronik. Perancangan berbasis elektronik mencakup pada instalasi yang terhubung dengan mikrokontroller. Berikut ini adalah diagram blok dari rancangan sistem palang pintu otomatis pada jalur BRT yang ditampilkan pada Gambar 1.

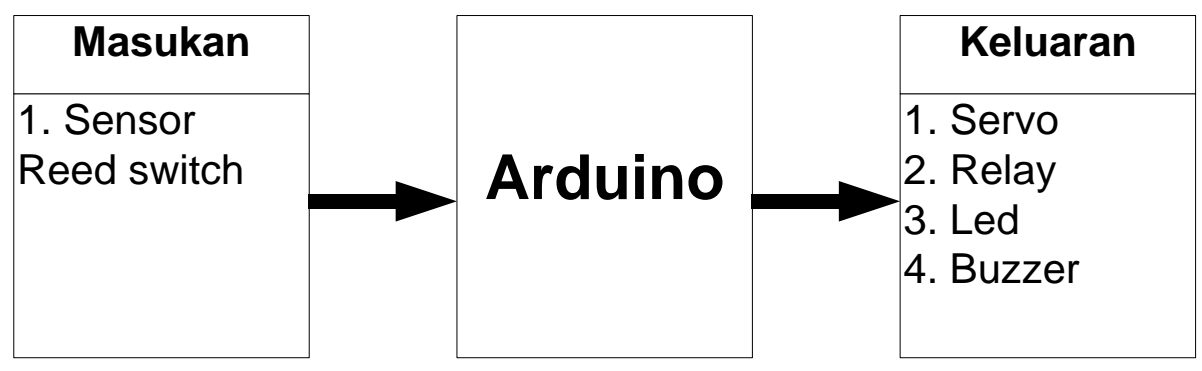

Gambar 1. Diagram blok 
Berdasarkan Gambar 1 dapat dilihat arduino sebagai pemroses masukan yang didapat dari sensor reed switch dan hasilnya akan dieksekusi oleh motor servo, led, relay dan buzzer.

\subsubsection{Rangkaian Arduino Leonardo}

Rancangan simulasi palang pintu otomatis pada jalur BRT ini menggunakan 4 buah motor servo sebagai penggerak palang-palang otomatis dan 8 buah sensor reed switch sebagai pendeteksi bus Transjakarta. Berikut ini adalah gambar rangkaian konfigurasi pin Arduino Leonardo untuk sistem palang pintu otomatis pada jalur BRT berbasis arduino yang ditampilkan pada Gambar 2.

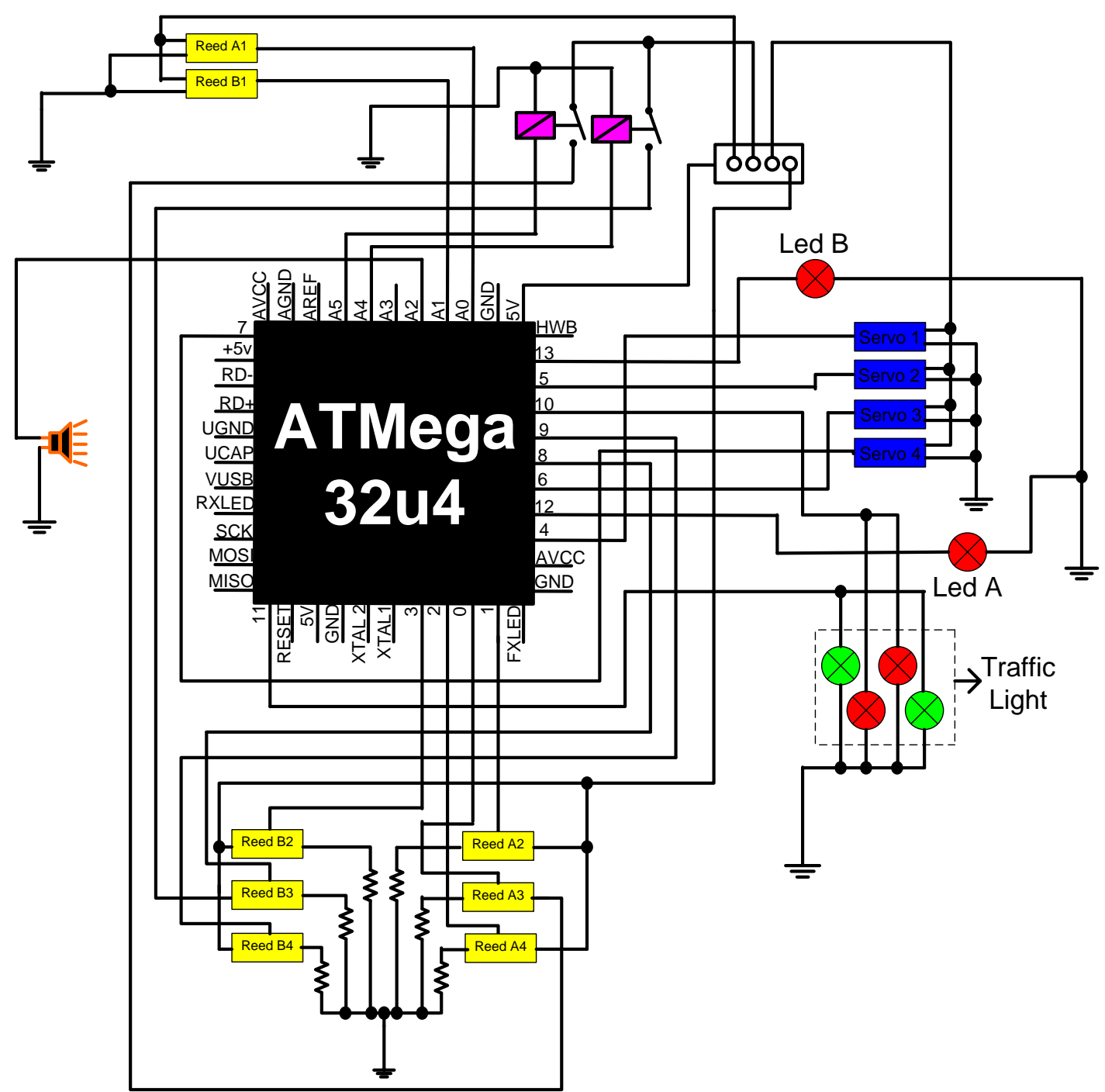

Gambar 2. Rangkaian pengkabelan pin Arduino Leonardo

Empat buah led digunakan sebagai simulasi lalu lintas dan buzzer sebagai suara peringatan kepada pengendara lain bahwa bus Transjakarta yang melintas.

\subsubsection{Simulasi Lalu Lintas}

Simulasi rancangan sistem palang pintu otomatis pada jalur BRT diletakkan pada jalur Transjakarta yang dipotong oleh kendaraan lain sebagai tempat putar arah jalur kendaraan. Berikut ini adalah simulasi lalu lintas sistem palang pintu otomatis BRT berbasis Arduino yang ditampilkan pada Gambar 3. 
Jurnal Ilmu Teknik Elektro Komputer dan Informatika (JITEKI)

Vol. 3, No. 2, Desember 2017

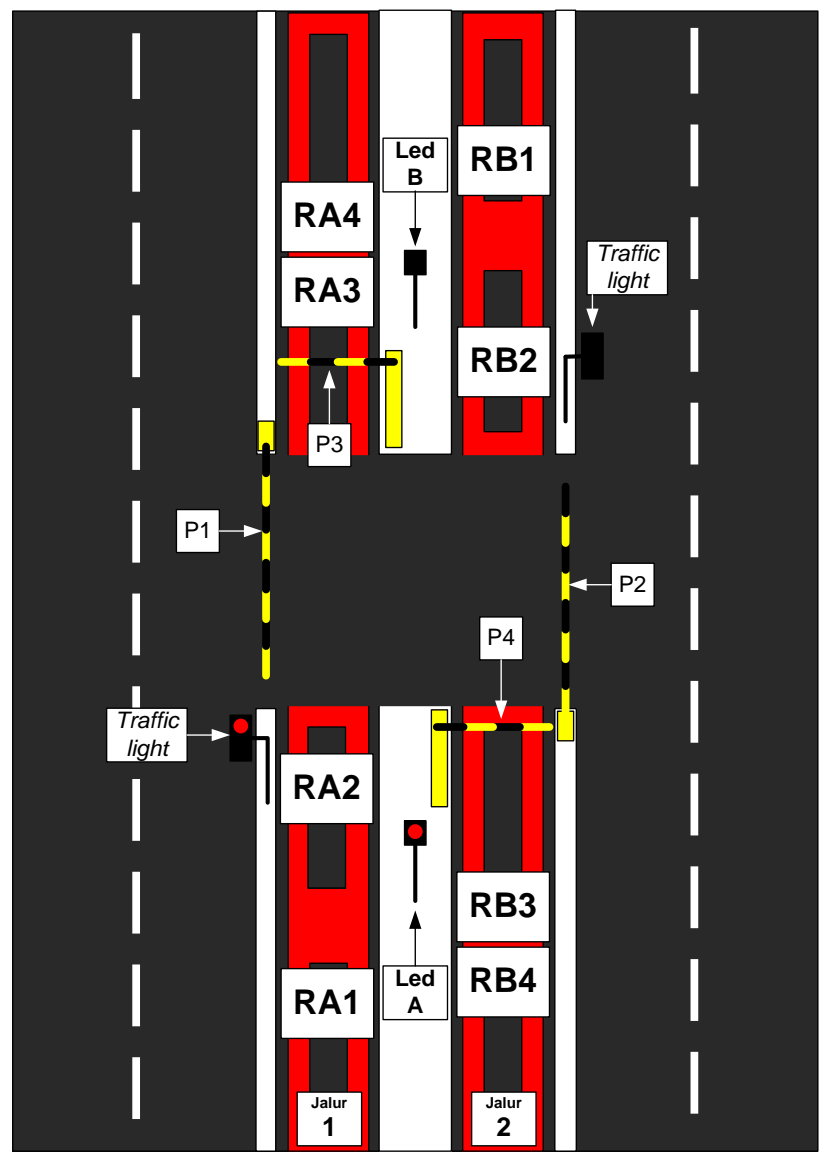

Gambar 3. Simulasi lalu lintas palang pintu otomatis pada jalur BRT

Sensor reed switch digunakan sebagai pendeteksi bus ditandai dengan huruf RA1, RA2, RA3, RA4, RB1, RB2, RB3, RB4. Led A dan Led B digunakan sebagai persinyalan bus, P1 digunakan sebagai palang penutup jalur umum, P2 digunakan sebagai palang penutup jalur 1 dan P3 digunakan sebagai palang penutup jalur 2.

\subsubsection{Perancangan Perangkat Lunak}

Perancangan perangkat lunak pada penelitian ini yaitu bertujuan untuk membuat semua sensor reed switch, led, motor servo, relay dan buzzer dapat terintegrasi dengan Arduino Leonardo. Berikut ini adalah tabel masukan dan tebel keluaran untuk sistem palang pintu otomatis pada jalur BRT berbasis Arduino yang ditampilkan pada Tabel 1 sebagai tabel masukan dan tabel 2 sebagai tabel keluaran.

Tabel 1. Masukan

\begin{tabular}{ccl}
\hline No & Masukan & \multicolumn{1}{c}{ Keterangan } \\
\hline 1 & RA1 & Sensor pendeteksi kedatangan bus di \\
2 & Ralur 1 & Sensor penutup P1 \& pembuka P2 \\
3 & RA3 & Sensor penutup P2 \& pembuka P1 \\
4 & RA4 & Sensor untuk mematikan sinyal Led A \\
5 & RB1 & Sensor pendeteksi kedatangan bus di \\
6 & RB2 & Sensor penutup P1 \& pembuka P3 \\
7 & RB3 & Sensor penutup P3 \& pembuka P1 \\
8 & RB4 & Sensor untuk mematikan sinyal Led B \\
\hline
\end{tabular}

Rancangan Sistem Palang Pintu Otomatis Pada Jalur Bus Rapid Transit Berbasis Arduino 
Tabel 2. Keluaran

\begin{tabular}{ccl}
\hline No & Keluaran & \multicolumn{1}{c}{ Keterangan } \\
\hline 1 & P1 & Palang pintu penutup jalur umum \\
2 & P2 & Palang pintu penutup jalur 1 \\
3 & P3 & Palang pintu penutup jalur 2 \\
4 & Led A & Persinyalan yang ada di jalur 1 \\
5 & Led B & Persinyalan yang ada di jalur 2 \\
6 & TL & Traffic light jalur umum \\
7 & Buzzer & Sirine peringatan bahwa ada busway yang \\
\hline
\end{tabular}

Dalam rancangan ini terdapat lima kondisi yang kemungkinan akan terjadi. Kondisi pertama adalah kondisi satu buah bus melintasi jalur 1, kondisi kedua adalah kondisi satu buah bus yang melintasi jalur 2, kondisi kedua adalah kondisi 2 buah bus atau lebih melintasi jalur 1 , kondisi kedua adalah kondisi 2 buah bus atau lebih melintasi jalur 2 dan yang kelima adalah kondisi 1 buah bus melintasi jalur 1 dan 1 buah bus melintasi jalur 2. Berikut ini adalah diagram keadaan sistem palang pintu otomatis pada jalur BRT berbasis Arduino yang ditampilkan pada Gambar 4 dan keterangan keadaannya ditampilkan pada Tabel 3.

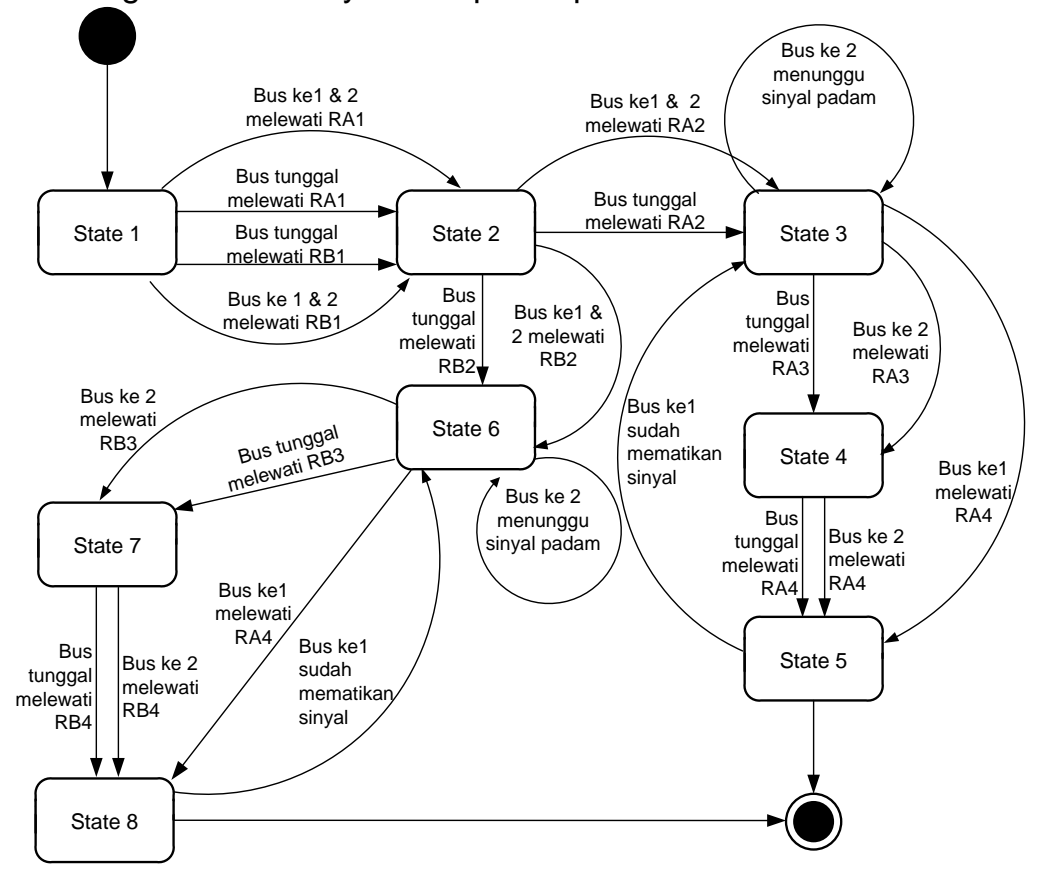

Gambar 4. Diagram Keadaan sistem palang pintu otomatis jalur BRT

Tabel 3. Tabel keadaan

\begin{tabular}{cl}
\hline Keadaan & \multicolumn{1}{c}{ Keterangan } \\
\hline State 1 & $\begin{array}{l}\mathrm{P} 1=\text { membuka, } \mathrm{P} 2=\text { menutup, } \mathrm{P} 3=\text { menutup, } \mathrm{TL}=\text { Hijau, buzzer }=\text { off } \\
\text { (kondisi normal) }\end{array}$ \\
State 2 & $\mathrm{TL}=$ Merah, buzzer $=$ on \\
State 3 & $\mathrm{P} 1=$ menutup, $\mathrm{P} 2=$ membuka, Led $\mathrm{A}=$ on \\
State 4 & $\mathrm{P} 1=$ membuka, $\mathrm{P} 2=$ menutup, $\mathrm{TL}=\mathrm{Hijau}$, buzzer $=$ off \\
State 5 & Led $\mathrm{A}=$ off \\
State 6 & $\mathrm{P} 1=$ menutup, $\mathrm{P} 3=$ membuka, Led $\mathrm{B}=$ on \\
State 7 & $\mathrm{P} 1=$ membuka, P3 = menutup, $\mathrm{TL}=\mathrm{Hijau}$, buzzer $=$ off \\
State 8 & Led $\mathrm{B}=$ off
\end{tabular}

Rancangan Sistem Palang Pintu Otomatis Pada Jalur Bus Rapid Transit Berbasis Arduino (A. Fauzi) 


\section{Hasil Dan Pembahasan}

\subsection{Pengujian Alat}

Pada tahap pengujian alat, yang dilakukan adalah dengan menguji semua perangkat yang dibuat baik itu perangkat keras maupun perangkat lunak. Dalam pengujian kita harus dapat memastikan perangkat yang kita buat sudah bisa berfungsi sebagaimana fungsi dari masingmasaing perangkat.

\subsubsection{Pengujian Sensor Reed switch}

Pengujian dilakukan dengan cara mendekatkan medan magnet ke titik sensitif dari sensor reed switch. Setelah dilakukan pengujian sebanyak 20 titik jarak yang berbeda dengan masingmasing jarak dilakukan 7 kali percobaan, maka didapatkan hasil yang ditampilkan pada Tabel 4 dan Gambar 5.

Tabel 4. Hasil pengujian sensor reed switch

\begin{tabular}{|c|c|c|c|c|c|c|c|c|}
\hline \multirow{2}{*}{$\begin{array}{l}\text { Jarak } \\
(\mathrm{mm})\end{array}$} & \multicolumn{7}{|c|}{ Percobaan } & \multirow{2}{*}{$\begin{array}{l}\text { Prosentase } \\
\text { Keberhasilan }\end{array}$} \\
\hline & 1 & 2 & 3 & 4 & 5 & 6 & 7 & \\
\hline 2 & membaca & membaca & Membaca & membaca & membaca & membaca & membaca & $100 \%$ \\
\hline 3 & membaca & membaca & Membaca & membaca & membaca & membaca & membaca & $100 \%$ \\
\hline 4 & membaca & membaca & Membaca & membaca & membaca & membaca & membaca & $100 \%$ \\
\hline 7 & membaca & membaca & Membaca & membaca & membaca & membaca & membaca & $100 \%$ \\
\hline 8 & membaca & membaca & Membaca & membaca & membaca & membaca & membaca & $100 \%$ \\
\hline 9 & membaca & membaca & Membaca & membaca & membaca & membaca & membaca & $100 \%$ \\
\hline 10 & membaca & membaca & Membaca & membaca & membaca & membaca & membaca & $100 \%$ \\
\hline 11 & membaca & membaca & Membaca & membaca & membaca & membaca & membaca & $100 \%$ \\
\hline 12 & membaca & membaca & Membaca & membaca & membaca & membaca & membaca & $100 \%$ \\
\hline 17 & tidak & membaca & Membaca & Tidak & tidak & tidak & membaca & $42 \%$ \\
\hline 18 & tidak & membaca & Membaca & Tidak & tidak & tidak & tidak & $28 \%$ \\
\hline 19 & membaca & tidak & Tidak & Tidak & tidak & tidak & tidak & $14 \%$ \\
\hline 20 & tidak & tidak & Tidak & Tidak & tidak & tidak & tidak & $0 \%$ \\
\hline
\end{tabular}

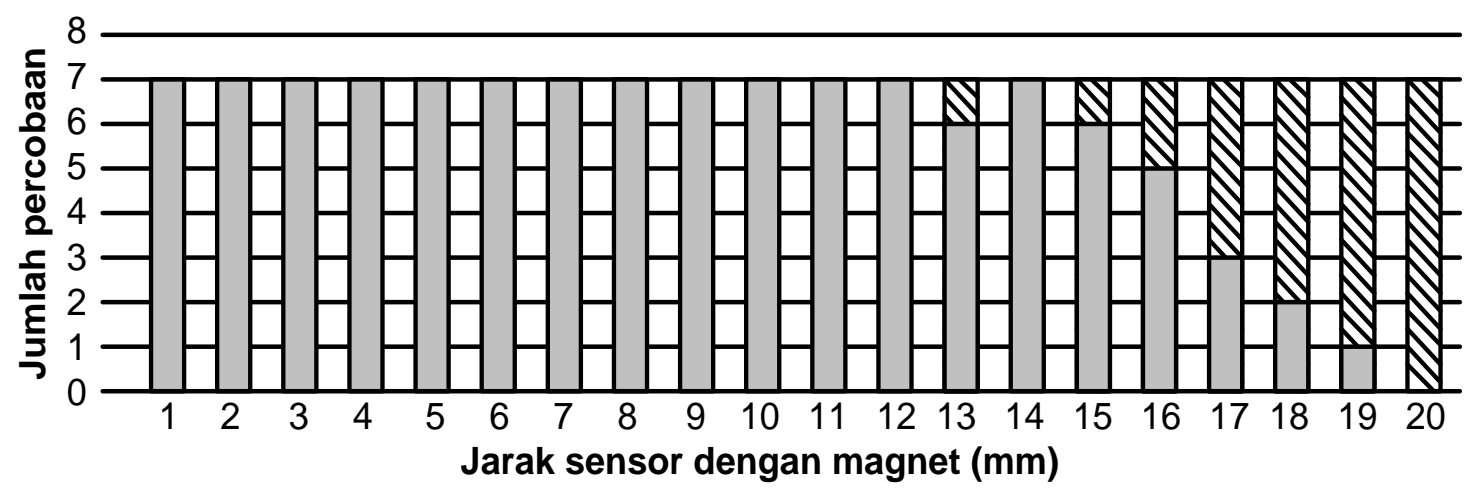

Terbaca

A Tidak Terbaca

Gambar 5. Grafik hasil pengujian sensor reed switch

Berdasarkan grafik pengujian sensor reed switch, ketidakpekaan sensor reed switch dimulai pada jarak $13 \mathrm{~mm}$ dimana dari 7 kali percobaan, hanya 6 kali yang berhasil, bahkan pada pengujian dengan jarak $20 \mathrm{~mm}$, sensor tidak dapat membaca keberadaan magnet. 


\subsubsection{Pengujian Alat Keseluruhan}

Pengujian alat dilakukan dengan cara menjalankan miniatur bus yang sudah dimodifikasi dengan menambahkan medan magnet pada bagian bawah bus pada sistem ini. Berikut ini adalah tampilan cara pengujian alat, yang ditampilkan pada Gambar 6 .

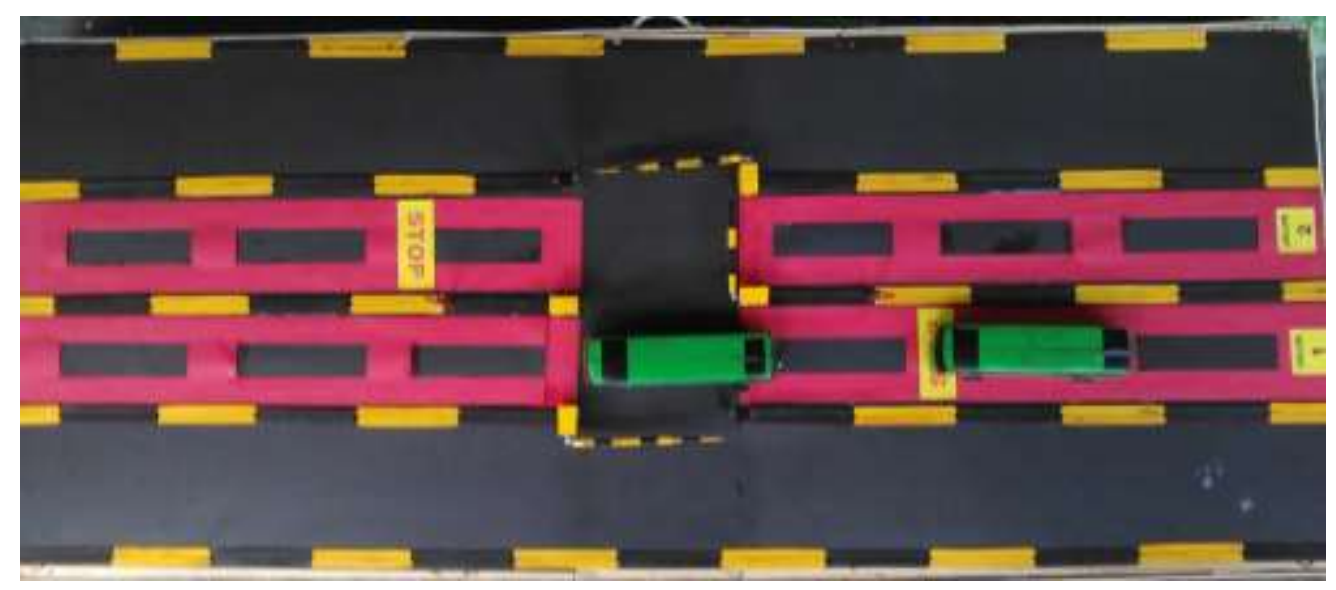

Gambar 6. Pengujian alat

Setelah dilakukan beberapa kali pengujian,untuk percobaan pertama yaitu 1 buah bus melintasi jalur 1 yang ditampilkan pada Tabel 5 .

\begin{tabular}{cc} 
Tabel 5. Hasil pengujian 1 buah bus melintasi jal \\
\hline Pengujian & Hasil \\
\hline 1 & Berhasil \\
2 & Berhasil \\
3 & Tidak \\
4 & Berhasil \\
5 & Berhasil \\
6 & Berhasil \\
7 & Berhasil \\
8 & Berhasil \\
9 & Berhasil \\
10 & Tidak \\
Prosentasi Keberhasilan & $80 \%$ \\
\hline
\end{tabular}

Setelah dilakukan percobaan sebanyak 10 kali pada pengujian 1 buah bus melintasi jalur 1 , prosentase tingkat keberhasilanya mencapai 80 persen dan 20 persen tidak berhasil. Percobaan kedua yaitu pengujian 1 buah buh melewati jalur 2 yang hasilnya ditampilkan pada Tabel 6.

Tabel 6 . Hasil pengujian 1 buah bus melintasi jalur 2

\begin{tabular}{cc}
\hline Pengujian & Hasil \\
\hline 1 & Berhasil \\
2 & Berhasil \\
3 & Berhasil \\
4 & Berhasil \\
5 & Berhasil \\
6 & Berhasil \\
7 & Berhasil \\
8 & Berhasil \\
9 & Berhasil \\
10 & Berhasil \\
Prosentasi Keberhasilan & $100 \%$ \\
\hline
\end{tabular}

Rancangan Sistem Palang Pintu Otomatis Pada Jalur Bus Rapid Transit Berbasis Arduino 
Setelah dilakukan percobaan sebanyak 10 kali pada pengujian 1 buah bus melintasi jalur 2, prosentase tingkat keberhasilanya mencapai 100 persen. Percobaan ketiga yaitu pengujian dengan 2 buah bus melintasi 1 jalur yang hasilnya akan ditampilkan pada Tabel 7 .

Tabel 7. Hasil pengujian 2 buah bus melintasi jalur1

\begin{tabular}{cc}
\hline Pengujian & Hasil \\
\hline 1 & Berhasil \\
2 & Berhasil \\
3 & Berhasil \\
4 & Berhasil \\
5 & Tidak \\
6 & Berhasil \\
7 & Berhasil \\
8 & Berhasil \\
9 & Berhasil \\
10 & Berhasil \\
Prosentasi Keberhasilan & $90 \%$ \\
\hline
\end{tabular}

Setelah dilakukan percobaan sebanyak 10 kali pada pengujian 2 buah bus melintasi jalur 1 , presentase tingkat keberhasilanya mencapai 80 persen dan 20 persen tidak berhasil. Percobaan keempat yaitu pengujian dengan 2 buah bus melintasi 2 jalur yang hasilnya akan ditampilkan pada Tabel 8.

Tabel 8. Hasil pengujian 2 buah bus melintasi jalur2

\begin{tabular}{cc}
\hline Pengujian & Hasil \\
\hline 1 & Tidak \\
2 & Berhasil \\
3 & Berhasil \\
4 & Berhasil \\
5 & Tidak \\
6 & Berhasil \\
7 & Berhasil \\
8 & Berhasil \\
9 & Berhasil \\
10 & Berhasil \\
Prosentasi Keberhasilan & $80 \%$ \\
\hline
\end{tabular}

Setelah dilakukan percobaan sebanyak 10 kali pada pengujian 2 buah bus melintasi jalur 2 , prosentase tingkat keberhasilanya mencapai 80 persen dan 20 persen tidak berhasil. Percobaan kelima yaitu pengujian dengan 1 buah bus melintasi jalur 1 dan 1 buah bus melintasi jalur 2 hasilnya akan ditampilkan pada Tabel 9.

Tabel 9. Hasil pengujian 1 buah bus melintasi jalur 1 dan 1 buah bus melintasi jalur 2

\begin{tabular}{cc}
\hline Pengujian & Hasil \\
\hline 1 & Berhasil \\
2 & Tidak \\
3 & Tidak \\
4 & Berhasil \\
5 & Berhasil \\
6 & Berhasil \\
7 & Berhasil \\
8 & Berhasil \\
9 & Berhasil \\
10 & Berhasil \\
Prosentasi Keberhasilan & $80 \%$ \\
\hline
\end{tabular}


Setelah dilakukan percobaan sebanyak 10 kali pada pengujian 1 buah bus melintasi jalur 1 dan 1 buah bus melintasi jalur 2, prosentase tingkat keberhasilanya mencapai 80 persen dan 20 persen tidak berhasil.

Beberapa kegagalan percobaan yang terjadi dikarenakan sensor tidak membaca magnet dengan baik. Hal-hal yang perlu diperhatikan dalam penggunaan sensor reed switch ini adalah kecepatan bus ketika melewati bagian sensor yang disarankan adalah $8 \mathrm{~km} / \mathrm{jam}$, agar sensor dapat membaca magnet yang ada di bagian bawah bus dengan baik dan sempurna.

\section{Kesimpulan}

Berdasarkan hasil penelitian dan pembahasan yang telah dilakukan mengenai rancangan sistem palang pintu otomatis pada bus rapid transit (BRT) bebasis arduino bahwa penelitian ini berhasil merancang sebuah sistem palang pintu otomatis pada jalur BRT dengan sensor reed switch sebagai pendeteksi busnya. Dalam pengujian sistem secara keseluruhan yang dilakukan masing-masing sebanyak 10 (sepuluh) percobaan, hasilnya adalah 4 pengujian memiliki tingkat keberhasilannya adalah $80 \%$ dan 1 pengujian tingkat keberhasilannya adalah $100 \%$. Unsurunsur penting dalam sistem ini adalah saat bus melewati sensor, kecepatan bus harus disesuaikan sehingga sensor dapat membaca saat bus melintasinya.

\section{Referensi}

[1] Rocky G, Klarawidya P. Statistik Daerah DKI Jakarta. Badan Pusat Statistiuk DKI Jakarta. Nomor laporan: 315501302. 2015.

[2] Dody R, Yayat R. Eds. Statistik Transportasi DKI Jakarta tahun 2015. Badan Pusat Statistik DKI Jakarta. Nomor laporan: 315401504. 2015.

[3] Sophie W, Fitriati R. Sistem Bus Rapid Transit Transjakarta Dalam Studi Rekayasa Sosial. Jurnal Transportasi. 2011; 11(1): 1-10.

[4] Imadudin S, Aprilli Y, Sasongko S. Palang Pintu Otomatis Dengan Countdown Sebagai Upaya Menghindari Kecelakaan Di Perlintasan Kereta. Jurnal Penelitian Mahasiswa (PELITA). 2016; 11(1): 24-34.

[5] Andrianto, H. \& Darmawan A. Arduino, belajar cepat dan pemrograman.Bandung;Informatika Bandung. 2016.

[6] Santoso, H. Panduan Praktis Arduino Untuk Pemula. Trenggalek; Elang Sakti.2015.

[7] Wilcher, D. Learn Electronics With Arduino. New York; Technology In Action.2012. 